\title{
FINANCIAL STATEMENT MANIPULATION IN FAILING SMALL AND MEDIUM-SIZED ENTERPRISES IN BOSNIA AND HERZEGOVINA
}

\author{
Elvisa Buljubasic Musanovic \\ International Burch University, Sarajevo, Bosnia and Herzegovina \\ Sanel Halilbegovic \\ International Burch University, Sarajevo, Bosnia and Herzegovina
}

\begin{abstract}
The overall objective of this research is to analyze the financial condition of failing companies prior to bankruptcy, in comparison with non-failing companies, which are matched on the industry, size, and timeperiod. The sample consists of 168 SMEs from the wholesale and retail industry, whose financial statements were analyzed for the 2011-2015 period. The analysis is primarily based on the ratio analysis and the models developed for bankruptcy prediction and financial statement manipulation. MannWhitney $U$ test is used to compare differences between failing and non-failing SMEs for a set of twenty variables. Research findings indicate that there is a significant difference between failing and non-failing SMEs, especially in accruals, asset quality, leverage, profitability, and liquidity. For the very first time in the transition economy of CEE Bosnia and Herzegovina, the pre-bankruptcy behavior of failing SMEs is analyzed, providing insights into potentially manipulated areas, which represent the main contribution of the research.
\end{abstract}

Keywords: financial distress, accounting manipulations, earnings management, wholesale and retail industry, Beneish M-score, Altman Z-score model

DOI: http://dx.doi.org/10.15549/jeecar.v8i4.692

\section{INTRODUCTION}

The challenges of transition economies, lack of transparency and monitoring, and high tax burdens represent an unfavorable business environment, especially for small and mediumsized enterprises. In such circumstances, companies may resort to undesirable financial reporting practices.
When faced with financial turmoil, companies are inclined to employ some creative accounting practices to improve their financial performance, primarily due to the company's stakeholders (suppliers, investors, banks, employees, etc.). Many companies, especially small and mediumsized, are heavily dependent on bank loans, which puts additional pressure on the company's management to falsify the financial reports. 
Having in mind that economic decisions are dependent on the accounting reports, the impact of fraudulent reporting is remarkably greater than one can contemplate. According to the Report to the Nations (Association of Certified Fraud Examiners, 2020), financial statement fraud, compared to corruption and asset misappropriation, is the least common type of fraud, but the costliest, with a median loss of $\$ 954.000$.

One of the most recent corporate financial scandals that affected the region of Southeast Europe is the Agrokor case (with the headquarters in Croatia), whose debt reached 5.4 billion euros, which accounts for $11 \%$ of Croatian GDP. According to Djuric and Jovanovic (2019), the causes of the Agrokor crisis were market expansion through acquisitions, financial fraud, and hidden debts, which brought the company within easy reach of bankruptcy.

When it comes to the transition economy of Bosnia and Herzegovina, the key economic challenges for SMEs are bureaucracy, corruption, a grey economy, and an inefficient tax system. Being confronted with these challenges on a daily basis poses a serious struggle for SMEs and their survival. During 2016/2017, 457 companies filed for bankruptcy, out of which 65 were SMEs in the wholesale and retail industry.

Therefore, the overall objective of this research is to analyze the financial condition of failing companies prior to bankruptcy, in comparison with non-failing companies, which are matched on industry, size, and time period. The analysis is primarily based on ratio analysis and the models developed for bankruptcy prediction and financial statement manipulation. The more specific objectives are to evaluate the applicability of the bankruptcy prediction model, Altman Z-score, on the SMEs in Bosnia and Herzegovina, to analyze the signs or red flags of financial statement manipulation in failing companies compared to the non-failing companies, and to investigate what accounting manipulation practices (or fraud schemes) are used in financial reporting. Given the financial statements covering the period 2011-2015, this research depicts what preceded the bankruptcy of SMEs in the wholesale and retail industry, points to fraudulent behavior, and indicates the successfulness of ratio analysis.
The main contribution of this research is reflected in the fact that for the very first time, the pre-bankruptcy behavior of failing companies in the wholesale and retail industry in the context of the CEE transition economy is analyzed from the forensic accounting perspective, providing insights into areas that are potentially manipulated, and lays down the basis for building the model for fraud prevention and detection.

The research paper consists of five sections: introduction, literature review, methodology, results and discussion, and conclusion. The introductory part describes the research problem, objective, and contribution of the study. The literature review provides a comprehensive review of the related studies and the basis for hypotheses development. In the methodology part, the sample and method of the data analysis are explained. The results and discussion section provide a detailed elaboration of findings in relation to study hypotheses and similar studies in the field. Finally, the conclusion section summarizes the whole research paper and gives recommendations for further research.

\section{LITERATURE REVIEW}

Profound and accurate analysis of company's financial statements can reveal early signs or red flags of financial distress and potential manipulative behavior, and in that way, prevent negative consequences for the company and its stakeholders. In the last fifty years, various models which are based on financial statement analysis have been developed; thus there are: model for bankruptcy prediction (Altman, 1968), earnings management models (Jones, 1991; Dechow, Sloan and Sweeney, 1995; Kothari et al. 2005), detection of earnings manipulation (Beneish, 1999), and predicting accounting misstatements (Dechow et al., 2011).

MacCarthy (2017) argues that the company which is exposed to certain financial troubles is more likely to engage in earnings manipulation through the change in depreciation rates, postponement in recognition of expenses, recording sales too early, recording fictitious sales, or using any other technique of creative accounting with the aim of demonstrating better financial performance. One of the widely used financial statement fraud detection methods is 
Beneish M-score model, recommended by the ACFE, as a tool to be used by auditors and certified fraud examiners. Harrington (2005) argues that auditors may use variables in the Mscore model in carrying out the SAS 99 requirement to be reasonably assured that financial statements are free from material misstatements. On the other side, the model helps certified fraud examiners to focus the investigation on suspect areas. Tarjo and Herawati (2015) have applied the M-score model to a sample of 70 Indonesian companies (35 fraud companies and 35 non-fraud companies), as a basis for building a data-mining model, covering the period from 2001 to 2014. The findings of the study indicate that the model was able to detect 27 out of 35 fraud companies. On the other side, for 28 out of 35 non-fraud companies, the model did not show signs of financial statement manipulation. According to the findings, the gross margin index, depreciation index, sales and general administration expenses index, and total accruals to total assets index significantly influenced the detection of financial statement fraud. The M-score model had received special attention when it was applied to the Enron's financial statements, indicating that the signs of earnings manipulation could have been discovered as early as of 1997 (Mahama, 2015). Analysis of Enron's financial statements from 1997 revealed signs of manipulation in three indices: gross margin index, asset quality index, and sales growth index. Warshavsky (2012) argues that the possibility to apply the M-score model to an individual company using one annual report, is one of the significant strengths of the model. As such, the model has been used as a basis for the development of logistic regression, with the aim of investigating the significance of various ratios in determining the likelihood of accounting manipulations. The analysis included 132 manufacturing companies listed on the Istanbul Stock Exchange, covering the period 2010-2012. Dani, Ismail, and Kamarudin (2013) investigated the ability of financial ratios to detect financial statement fraud in Malaysia, using the sample of 122 companies (61 fraud and 61 non-fraud company), covering the period 2003-2010. The study found that all variables used in the M-score model, except gross margin index, have significant power to detect fraudulent financial statements. Given the widespread use of the Mscore model, the research hypotheses are:

H1: The Beneish M-score model has the ability to identify financial statement manipulation in financially distressed companies.

H2: Prior to bankruptcy, failing companies are more likely to engage in financial statement manipulation compared to non-failing companies.

In addition to the financial statement fraud detection models, there are models developed to predict the bankruptcy of companies. Such a model was developed by Altman in 1968. Since then, many research studies have used the model to analyze the company's financial condition and the likelihood of going bankrupt. Gerantonis, Vergos, and Christopoulos (2009), in their research study, analyzed the ability of the Altman Z-score model in predicting the bankruptcy of Athens Exchange companies during the period 2002-2008. The results showed that the Altman Z-score has the power to predict the failure of the companies, with greater accuracy rate one to two years before it actually happens. Kiaupaite-Grushniene (2016) has used the Altman Z-score model for analyzing the financial condition of agricultural companies in Lithuania. The findings indicate that the model correctly identified the companies associated with financial distress, as well as the companies that were running smoothly, having no financial difficulties. The study provides support to the Altman Z-score model, pointing out that it can be used as a practical tool in insolvency risk assessment and taking on appropriate risk management steps. In the study conducted by Ofori (2016), M-score and Z-score models were applied to the financial statements of Enron corporation for the period 1997-2001. The analysis revealed that both models were able to detect signs of earnings manipulation and possible bankruptcy as early as of 1997. Based on the study conducted by Lesáková, Gundová, and Vinczeová (2020), companies in Slovakia are using the Z-score model to make predictions about future performance. Boda and Uradnicek (2016) analyzed the portability of the Z-score model to the Slovak business environment, where they found out that the model is portable 
to Slovakia and useful in predicting financial distress with the prediction accuracy of $75 \%-80 \%$. However, they advise reestimating the coefficients if the goal is to classify financially distressed companies as best as possible. This is aligned with Csikosova, Janoskova, and Culkova (2019), who conducted research in postcommunist countries, claiming that it is advisable to adjust coefficients of the Z-score model depending on the industry in chosen countries despite the relatively high prediction ability of the model. According to Bisogno, Restaino, and Di Carlo (2018) and Csikosova et al. (2019), the Z-score model is a widely used and recognized measure of financial distress in the existing literature. Therefore, the next research hypothesis is:

\section{H3 - The Altman Z-Score is applicable to the analysis of financial statements of $\mathrm{BH}$ companies and bankruptcy prediction.}

Given the number of available techniques and models for the detection of financial distress and potential financial statement manipulation, one can use those techniques and models as a group to make inferences about a company's prospects. The study developed by Grove, Cook, Streeper, and Throckmorton (2010) used six different models and ratios (quality of earnings ratio, quality of revenues ratio, Sloan accrual measure, Altman Z-score, Beneish M-score, and F-score model) to devise a comprehensive approach that would screen and identify problems in the financial reporting process. The findings of that study demonstrate that such an approach helps a company's stakeholders to guide their decisionmaking process and auditors to focus their further investigation. Furthermore, Ogachi, Ndege, Gaturu, and Zoltan (2020) argue that the combination of different ratios that are used as classification tools and for bankruptcy prediction can help in the selection of financial ratios that would enhance predication accuracy. Also, Ogachi et al. (2020) state that financially distressed companies are usually smaller, highly leveraged, and with very low liquidity, solvency, and profitability ratios. In the study conducted on earnings management among bankrupt nonlisted companies, the authors found that financially distressed companies are using a combination of sales and production cost manipulation with the aim of prolonging the legal procedures, where these practices become evident at least four years prior to bankruptcy (Campa \& Minano, 2014). The study was done by Dalnial, Kamaluddin, Sanusi, and Khairuddin (2014) with a focus on the ratios that distinguish between fraudulent and non-fraudulent companies, found that leverage, capital turnover, and overall financial condition (Z-score) have significant discriminating power. Therefore, the last hypothesis of this research is:

\section{H4: Ratio analysis helps to prevent and detect fraudulent behavior.}

This research contributes to the existing literature in a number of ways. For the very first time, it analyzes the pre-bankruptcy behavior of failing SMEs, and investigates the signs of potential earnings manipulation in the transition economy of CEE, Bosnia and Herzegovina, which is characterized by the lack of political will to create a single economic space and expensiveness and difficulty of accessing financial statement data of non-listed private companies. Furthermore, the sample consists of the non-listed SMEs in the wholesale and retail industry, which is the second largest industry in terms of contribution to the country's GDP, the number of employees, and turnover. That is what increases the relevance of the research. Moreover, access to financing represents a difficulty for SMEs, especially due to the fact that the capital market is in its initial phase of development, thus being specific for countries in the transition process. Therefore, households and companies are primarily dependent on bank loans as almost the only source of finance. According to the Analytical Report of the European Commission (2019), the percentage of loans to households and companies has increased from 50\% of GDP in 2009 to approximately $60 \%$ at the end of 2018 . Being limited to loans as the only funding alternative brings SMEs under the pressure of meeting all bank requirements. Hence, analyzing the financial condition of SMEs which are confronted with the above-mentioned challenges should reveal interesting findings that will enrich the existent literature. 


\section{METHODOLOGY}

The sample of the research consists of 168 small and medium-sized, non-listed SMEs from the wholesale and retail industry in Bosnia and Herzegovina. This sample is composed of two sub-samples: 65 failing companies that filed for bankruptcy in 2016 and 103 non-failing companies. Even though the data was available for the period 2008-2015, the first three years were excluded from the analysis since in the year 2010 , the new Rulebook on the content and form of financial statements was introduced. That significantly affected the comparability of financial statements data before and after the Rulebook introduction. Therefore, the financial statements of the sampled companies were analyzed only for the period 2011-2015. The Zscore model developed by Altman (1983) for private, non-listed companies was applied to the financial statements of the failing companies to test its applicability. The formula for the Z-Score model follows:

$$
\begin{aligned}
& \text { Z-Score }=0.717(\mathrm{X} 1)+0.847(\mathrm{X} 2)+3.107(\mathrm{X} 3)+ \\
& 0.42(\mathrm{X} 4)+0.998(\mathrm{X} 5), \\
& \text { where } \\
& \mathrm{X} 1=\text { working capital/total assets, } \\
& \mathrm{X} 2=\text { retained earnings/total assets, } \\
& \mathrm{X} 3=\text { earnings before interest and taxes/total } \\
& \text { assets, } \\
& \mathrm{X} 4=\text { book value of equity/total liabilities, } \\
& \mathrm{X} 5=\text { sales/total assets. }
\end{aligned}
$$

Depending on the value of Z-score the company will be classified as:

Z-score $<1.23$ - bankrupt zone

Z-score between 1.23 and 2.90 - gray zone

Z-score $>2.90$ - safe zone

The M-score model is used to evaluate the possibility of earnings management. The model developed in 1999 distinguishes between manipulated and non-manipulated reporting practices. It includes eight variables: days sales in receivables index (DSRI), gross margin index (GMI), asset quality index (AQI), depreciation index (DEPI), sales growth index (SGI), sales general and administrative expenses index
(SGAI), leverage index (LVGI) and total accruals to total assets index (TATA).

M-Score $=-4.84+0.92 *$ DSRI $+0.528^{*} \mathrm{GMI}+$
$0.404^{*} \mathrm{AQI}+0.892^{*} \mathrm{SGI}+0.115^{*} \mathrm{DEPI}-$
$0.172^{*} \mathrm{SGAI}+4.679^{*} \mathrm{TATA}-0.327^{*} \mathrm{LVGI}$

The company will be classified as a potential manipulator if M-score is higher than -1.78 and otherwise as a non-manipulator.

In addition to the Z-score and M-score model, the Mann-Whitney $U$ test was used to examine the differences between failing and non-failing companies by observing variables in the abovementioned models plus variables that are indicators of liquidity, solvency, and profitability: working capital productivity, current ratio, debt ratio, return on equity, return on assets, receivable turnover ratio and asset composition ratios (current assets to total assets, receivables to total assets and inventories to total assets).

\section{RESULTS AND DISCUSSION}

The Z-score model was applied to the financial statements of failing and non-failing companies for each year in the period 2011-2015. The analysis of this four-year period reveals the following: Z-score for 29 out of 65 failing companies was below 1.23, which classifies these companies as financially distressed companies or companies that are heading for bankruptcy; 11 companies were in gray zone, while the rest, 25 companies were in the safe zone. However, some of the companies that were classified as safe had a significant increase in Zscore just one year before filing for bankruptcy. These examples are shown in Table 1 below, where the Z-score is accompanied by M-score results (YES - potential manipulation, NO - no manipulation). According to these findings, the Z-score correctly predicted only $44 \%$ of failing companies as financially distressed. The results are impaired by the fact that $32 \%$ of companies classified as safe had an abnormal increase in Zscore in the year preceding the bankruptcy. Following the M-score results, a very high Zscore was associated with the possible manipulation of financial statements, which is shown in Table 1 . This is aligned with the study 
of Liou and Yang (2008), who claim that manipulation of financial information distorts the accuracy of bankruptcy prediction.

Table 1: Relation between Altman Z-score and Beneish M-score model

\begin{tabular}{|c|c|c|c|c|c|c|c|c|}
\hline \multirow{2}{*}{ Company } & \multicolumn{4}{|c|}{ Altman Z-score } & \multicolumn{4}{c|}{ Beneish M-score } \\
\cline { 2 - 9 } & $\mathbf{2 0 1 5}$ & $\mathbf{2 0 1 4}$ & $\mathbf{2 0 1 3}$ & $\mathbf{2 0 1 2}$ & $\mathbf{2 0 1 5}$ & $\mathbf{2 0 1 4}$ & $\mathbf{2 0 1 3}$ & $\mathbf{2 0 1 2}$ \\
\hline 1 & 24.899 & 4.3256 & 3.2041 & 3.071 & YES & NO & NO & YES \\
\hline 2 & 18.669 & 11.0178 & 4.5412 & 4.3765 & NO & YES & NO & YES \\
\hline 3 & 63.747 & 2.642 & 3.3067 & 4.3045 & YES & NO & NO & NO \\
\hline 4 & 6.184 & 3.9627 & 3.0768 & 3.1027 & YES & NO & NO & NO \\
\hline 5 & 25.375 & 3.2844 & 2.4457 & 6.29144 & YES & NO & NO & YES \\
\hline 6 & 11.838 & 3.4652 & 4.0358 & 3.6170 & YES & NO & YES & NO \\
\hline 7 & 21.703 & 4.1208 & 3.6143 & 3.3611 & YES & NO & YES & NO \\
\hline 8 & 4.967 & 1.8337 & 1.5729 & 2.0125 & YES & NO & NO & NO \\
\hline
\end{tabular}

Source: Author's work.

Detailed analysis of the above-mentioned company's financial statements reveals the following in the year preceding the bankruptcy: a significant drop in working capital productivity, and an abnormal increase in the following: RE/TA ratio, productivity (EBIT/TA), asset turnover, TATA ratio, ROA, ROE, and receivables turnover ratio, which resulted in an abnormal increase in Z-score. Besides, over a four-year period, the following red flags were detected: decline in gross margins, revenue inflation, involvement in cost deferral, and increase in leverage. However, Hypothesis 3, which states that the Altman Z-score model is applicable to the analysis of financial statements of $\mathrm{BH}$ companies and bankruptcy prediction, cannot be fully confirmed. The prediction ability of Altman's Z-score model is low compared to the other studies that have been done in the countries of CEE, such as Slovakia (Boda and Uradnicek, 2016), Lithuania (KiaupaiteGrushniene, 2016), and the Czech Republic (Kubickova and Nulicek, 2019).

After screening for outliers, the Mann Whitney $\mathrm{U}$ test was applied to the variables in the Z-score model to evaluate the differences between failing and non-failing companies over a fouryear period accompanied by descriptive statistics. Table 2 shows that three out of five variables in the model discriminate between failing and non-failing companies: WC/TA with the evident difference in all years except 2012, EBIT/TA with the evident difference in all years except 2012, and the book value of equity/TL with an evident difference across all four years. The significant drop in the WC/TA ratio for failing companies shows that current liabilities overstate current assets, leading the company to a state of insolvency. Even though the Mann Whitney U test does not reveal any significant difference between failing and non-failing companies for RE/TA, there is an interesting observation regarding the mean values, in which the ratio almost doubles one year before filing for bankruptcy (increases from 0.25 in 2014 to 0.44 in 2015). Also, there is an increase in mean and median values for productivity ratio (increase in mean value from 0.14 in 2014 to 0.23 in 2015). This may serve as an indication of revenue inflation or a record of fictitious revenues, which resulted in the income increase for failing companies. Following Perols and Loguee (2011), fraudulent companies intentionally inflate revenues to maintain positive earnings. When it comes to the book value of equity relative to total liabilities, the median values are notably declining for failing companies, from 0.25 in 2012 to 0.12 in 2015 , while the median values for non-failing companies are around 0.45 across all four years. Based on the Mann-Whitney U test, the asset turnover ratio does not depict a significant difference between failing and nonfailing companies. However, by observing asset 
turnover for failing companies, one can notice a huge drop in mean and median values from 2012 to 2015 , demonstrating that the revenuegenerating power of total assets is declining. These findings are in line with Ogachi el al. (2020), who argue that financially distressed companies are usually highly leveraged, and with very low liquidity, solvency, and profitability ratios.

Table 2: Mann-Whitey U-test for Altman Z-score variables

\begin{tabular}{|c|c|c|c|c|c|c|}
\hline \multirow[t]{2}{*}{ Variable } & \multicolumn{2}{|c|}{$\begin{array}{c}\begin{array}{c}\text { Bankrupt } \\
\text { companies } \\
N=65\end{array} \\
\end{array}$} & \multicolumn{2}{|c|}{$\begin{array}{c}\text { Non-bankrupt } \\
\text { companies } \\
N=103\end{array}$} & \multirow{2}{*}{$\begin{array}{c}\text { Mann- } \\
\text { Whitney } U\end{array}$} & \multirow[t]{2}{*}{ p-value } \\
\hline & Mean & Median & Mean & Median & & \\
\hline WC/TA 2012 & 0.09 & 0.15 & 0.17 & 0.15 & 3134 & 0.487 \\
\hline WC/TA 2013 & 0.04 & 0.08 & 0.23 & 0.22 & 2715 & 0.039 \\
\hline WC/TA 2014 & 0.013 & 0.09 & 0.23 & 0.27 & 2755 & 0.054 \\
\hline WC/TA 2015 & -0.06 & -0.11 & 0.24 & 0.27 & 2323 & 0.001 \\
\hline RE/TA 2012 & 0.24 & 0.18 & 0.28 & 0.22 & 2893 & 0.242 \\
\hline RE/TA 2013 & 0.25 & 0.16 & 0.32 & 0.26 & 2814 & 0.152 \\
\hline RE/TA 2014 & 0.25 & 0.17 & 0.32 & 0.26 & 2770 & 0.114 \\
\hline RE/TA 2015 & 0.44 & 0.17 & 0.34 & 0.26 & 3035 & 0.485 \\
\hline EBIT/TA 2012 & 0.11 & 0.08 & 0.09 & 0.06 & 3072 & 0.636 \\
\hline EBIT/TA 2013 & 0.11 & 0.09 & 0.08 & 0.05 & 2535 & 0.059 \\
\hline EBIT/TA 2014 & 0.14 & 0.09 & 0.07 & 0.04 & 2339 & 0.003 \\
\hline EBIT/TA 2015 & 0.23 & 0.12 & 0.09 & 0.05 & 2181 & 0.001 \\
\hline BV of equity/TL 2012 & 0.3 & 0.25 & 0.42 & 0.42 & 2599.5 & 0.015 \\
\hline BV of equity/TL 2013 & 0.28 & 0.19 & 0.46 & 0.46 & 2295.5 & 0.001 \\
\hline BV of equity/TL 2014 & 0.28 & 0.18 & 0.46 & 0.44 & 2313 & 0.001 \\
\hline BV of equity/TL 2015 & 0.29 & 0.12 & 0.47 & 0.45 & 2107.5 & 0.000 \\
\hline Sales/TA 2012 & 2.08 & 1.26 & 1.35 & 1.17 & 2897 & 0.248 \\
\hline Sales/TA 2013 & 1.74 & 1.17 & 1.26 & 1.05 & 3040 & 0.496 \\
\hline Sales/TA 2014 & 1.52 & 0.99 & 1.18 & 1.02 & 3118 & 0.801 \\
\hline Sales/TA 2015 & 1.59 & 0.81 & 1.29 & 1.09 & 3041 & 0.609 \\
\hline
\end{tabular}

Source: Author's work.

When it comes to the M-score model, 41 out of 65 failing companies (or 63\%) had an M-score higher than -1.78 , which indicates potential financial statement manipulation. On the other side, out of 103 non-failing companies, only 8 companies were classified as potential financial statement manipulators throughout the fouryear period. By applying the Mann-Whitney U test to the components of the M-score model, the significant difference between failing and nonfailing companies is evident in the following:
GMI in 2014, AQI across all four years, TATA and LVGI in 2014 and 2015, SGI in all years except 2012, and SGAI in the year preceding the bankruptcy. The mean values of GMI for failing companies are higher than 1 in all years except 2013, which serves as an indication of deteriorating gross margins where the likelihood of financial statement manipulation increases. AQI is an indicator of asset quality, where the value is higher than 1 point to the possibility of the company's involvement in cost deferral. 
Table 3 shows that AQI mean values are higher than 1 across a four-year period for failing companies, while the AQI mean values for nonfailing companies are around 1. TATA ratio's mean and median values for failing companies show a significant increase in the year prior to bankruptcy compared to the non-failing companies, pointing to the higher likelihood of earnings manipulation. This is in line with Chen, Chen, and Huang (2010), who conducted a study in China, which is also a transition economy, on the topic of earnings management among financially distressed listed and non-listed companies. The findings of this study indicate that after reporting a loss for two consecutive years, companies started to increase their reported earnings by earning management practices using discretionary accruals. Also, Perols and Loguee (2011) empirically tested and confirmed the positive relationship between discretionary accruals and earnings management. The reason behind measuring accruals is to evaluate their impact on net income and future cash-flows. Some accruals such as allowance for bad debts, warranty or inventory reserves are subject to the management estimates and therefore serve as an excellent method to manipulate financial statements. There are several models developed to evaluate the role of accruals in earnings management or income smoothing, such as: Dechow-Dichev accrual quality, Sloan's accruals, and Jones' nondiscretionary accruals (Dechow \& Dichev, 2002; Sloan, 1996; Jones, 1991). While not every income smoothing might comprise fraud, intentional misrepresentation of financial statements to misguide the reader does. LVGI values indicate that there is an increase in leverage of failing companies, especially one year prior to filing for bankruptcy, which indicates that a state of financial distress urged companies to reach out for bank loans. This is aligned with the Abu Bakar and Bin Yahya (2021) study conducted in Singapore in the period 2011-2015 and Ogachi et al. (2020), who found that financially distressed companies have a much higher debt ratio compared to healthy companies. In addition to debt ratio, interest coverage, return on assets, current ratio, and cash to total assets was among selected ratio variables that significantly contributed to the prediction of financial distress (Abu Bakar \& Bin Yahya, 2021). Furthermore, Bisogno and De Luca (2015) analyzed the relationship between financial distress and earnings management among nonlisted SMEs in Italy, where they found that failing companies, compared to non-failing ones, are more likely to report fraudulent financial statements, especially due to financial dependence on banks. When it comes to the economies of CEE countries, according to the study conducted in Slovakia, which analyzes the earnings management practices and fraudulent reporting, Svabova, Kramarova, Chutka, and Strakova (2020) found that changes in leverage were linked to the technical default of the company. The result of their study is the fraud detection model based on the Beneish M-score variables but adapted to the conditions of the business environment in Slovakia, whose predictive ability was greater than that of the Mscore model.

Based on SGI values, sales revenue for failing companies constantly deteriorated over the fouryear period, while for non-failing companies, it was kept stable from year to year, and the MannWhitney $U$ test shows that difference is significant in all years except 2012 .

The above-stated findings support Hypotheses 1 and 2, indicating that the M-score has the ability to predict financial statement manipulation in financially distressed companies and that those companies are more likely to engage in the manipulation compared to the non-failing companies. 
Table 3: Mann-Whitey U-test for Beneish M-score variables

\begin{tabular}{|c|c|c|c|c|c|c|}
\hline \multirow[t]{2}{*}{ Variable } & \multicolumn{2}{|c|}{$\begin{array}{c}\text { Bankrupt } \\
\text { companiesn } \mathrm{N}=65\end{array}$} & \multicolumn{2}{|c|}{$\begin{array}{c}\text { Non-bankrupt } \\
\text { companies } \\
\mathrm{N}=103 \\
\end{array}$} & \multirow{2}{*}{$\begin{array}{c}\text { Mann- } \\
\text { Whitney U }\end{array}$} & \multirow[t]{2}{*}{ p-value } \\
\hline & Mean & Median & Mean & Median & & \\
\hline GMI 2012 & 1.02 & 1 & 0.96 & 1 & 2572 & 0.142 \\
\hline GMI 2013 & 0.95 & 0.99 & 0.97 & 1 & 2604.5 & 0.458 \\
\hline GMI 2014 & 1.1 & 1 & 1.05 & 1 & 2541.5 & 0.04 \\
\hline GMI 2015 & 1.11 & 1 & 1.01 & 1 & 2583.5 & 0.182 \\
\hline AQI 2012 & 1.28 & 1 & 1.03 & 1 & 2462 & 0.017 \\
\hline AQI 2013 & 1.85 & 1 & 1 & 1 & 2451 & 0.076 \\
\hline AQI 2014 & 1.39 & 1 & 0.89 & 1 & 2165.5 & 0 \\
\hline AQI 2015 & 1.19 & 1 & 0.96 & 1 & 2647 & 0.009 \\
\hline TATA 2012 & 0.009 & 0 & -0.029 & -0.024 & 2716 & 0.493 \\
\hline TATA 2013 & 0.03 & 0.006 & 0.02 & 0.004 & 2378 & 0.116 \\
\hline TATA 2014 & 0.019 & 0.001 & -0.03 & -0.02 & 2717 & 0.05 \\
\hline TATA 2015 & 0.17 & 0.05 & -0.006 & -0.004 & 2461 & 0.007 \\
\hline LVGI 2012 & 1.14 & 1.01 & 1 & 0.99 & 2389 & 0.097 \\
\hline LVGI 2013 & 1.02 & 1 & 0.95 & 0.95 & 2633 & 0.724 \\
\hline LVGI 2014 & 0.98 & 1 & 1.08 & 0.99 & 2504 & 0.009 \\
\hline LVGI 2015 & 1.11 & 1.004 & 0.97 & 0.96 & 2464 & 0.009 \\
\hline SGI 2012 & 0.99 & 0.95 & 0.98 & 0.96 & 2683 & 0.329 \\
\hline SGI 2013 & 0.79 & 0.85 & 1 & 0.98 & 1785 & 0.000 \\
\hline SGI 2014 & 0.82 & 0.89 & 1.04 & 1.02 & 1887 & 0.000 \\
\hline SGI 2015 & 0.74 & 0.68 & 1.08 & 1 & 1447 & 0.000 \\
\hline SGAI 2012 & 1.07 & 1.03 & 1.1 & 1.06 & 2666 & 0.36 \\
\hline SGAI 2013 & 1.17 & 1.05 & 1.08 & 1.02 & 2438 & 0.239 \\
\hline SGAI 2014 & 1.21 & 0.99 & 1.09 & 0.97 & 3210 & 0.909 \\
\hline SGAI 2015 & 1.41 & 1.12 & 0.97 & 0.98 & 2172 & 0.000 \\
\hline
\end{tabular}

Source: Author's work.

This research aims to explore the discriminating power of selected ratios from the group of liquidity, solvency, profitability, and asset composition ratios. Table 4 confirms that those ratios have high discriminating power between failing and non-failing companies over the four-year period, which confirms Hypothesis 4 along with the results of the Z-score and Mscore model. Ratio analysis can detect and predict fraudulent behavior. Failing companies are characterized by the decline in the following: working capital productivity, current ratio, and receivables turnover ratio; very low ROA and ROE; and increase in the debt ratio. Regarding the asset composition ratios, only INV/TA ratio reveals a significant difference between failing and non-failing companies in 2014 and 2015. Findings for non-failing companies demonstrate a stronger liquidity position, lower leverage, higher RTR, higher ROA and ROE. 
Table 4: Mann-Whitey U-test for selected ratio variables

\begin{tabular}{|c|c|c|c|c|c|c|}
\hline \multirow[t]{2}{*}{ Variable } & \multicolumn{2}{|c|}{$\begin{array}{l}\text { Bankrupt companies } \\
\qquad \mathrm{N}=65\end{array}$} & \multicolumn{2}{|c|}{$\begin{array}{c}\text { Non-bankrupt } \\
\text { companies } \mathrm{N}=103\end{array}$} & \multirow{2}{*}{$\begin{array}{c}\text { Mann- } \\
\text { Whitney U }\end{array}$} & \multirow{2}{*}{$\begin{array}{c}\mathrm{p}- \\
\text { value }\end{array}$} \\
\hline & Mean & Median & Mean & Median & & \\
\hline WCP 2012 & 2.48 & 2.13 & 2.63 & 2.95 & 3171 & 0.807 \\
\hline WCP 2013 & 4.4 & 1.88 & 2.76 & 2.81 & 3031 & 0.839 \\
\hline WCP 2014 & 3.11 & 1.05 & 1.69 & 2.69 & 2921 & 0.282 \\
\hline WCP 2015 & 2.37 & 0.061 & 2.29 & 2.53 & 2623 & 0.027 \\
\hline CR 2012 & 1.6 & 1.23 & 1.65 & 1.32 & 2928 & 0.330 \\
\hline CR 2013 & 1.56 & 1.16 & 1.95 & 1.48 & 2481 & 0.020 \\
\hline CR 2014 & 1.61 & 1.12 & 2 & 1.45 & 2638 & 0.047 \\
\hline CR 2015 & 1.72 & 0.84 & 1.97 & 1.53 & 2200 & 0.001 \\
\hline DR 2012 & 67.82 & 72.9 & 56.29 & 56.9 & 2591 & 0.014 \\
\hline DR 2013 & 69.03 & 79.2 & 52.8 & 51.52 & 2279 & 0.001 \\
\hline DR 2014 & 67.89 & 75.3 & 53.34 & 54.54 & 2332.5 & 0.001 \\
\hline DR 2015 & 69.61 & 85.86 & 51.06 & 53.73 & 2091 & 0.000 \\
\hline RTR 2012 & 8.78 & 4.53 & 10.27 & 5.92 & 2388 & 0.051 \\
\hline RTR 2013 & 6.53 & 3.79 & 10.73 & 5.98 & 2293 & 0.006 \\
\hline RTR 2014 & 8.16 & 3.9 & 9.19 & 5.56 & 2080 & 0.008 \\
\hline RTR 2015 & 9.74 & 3.69 & 11.07 & 5.51 & 2350 & 0.025 \\
\hline ROA 2012 & 0.03 & 0 & 0.05 & 0.019 & 2378 & 0.002 \\
\hline ROA 2013 & 0.02 & 0 & 0.04 & 0.013 & 2096 & 0.000 \\
\hline ROA 2014 & 0.02 & 0 & 0.04 & 0.018 & 1625 & 0.000 \\
\hline ROA 2015 & 0.04 & 0 & 0.05 & 0.018 & 1775.5 & 0.000 \\
\hline ROE 2012 & 0.83 & 0.01 & 2.72 & 0 & 2058 & 0.000 \\
\hline ROE 2013 & 0.78 & 0.008 & 2.7 & 0.487 & 2051.5 & 0.000 \\
\hline ROE 2014 & 1.91 & 0 & 2.48 & 0.63 & 1578 & 0.000 \\
\hline ROE 2015 & 0.91 & 0 & 2.75 & 0.51 & 1334 & 0.000 \\
\hline \multicolumn{7}{|c|}{ ASSET COMPOSITION } \\
\hline CA/TA 2012 & 0.71 & 0.82 & 0.65 & 0.76 & 2762 & 0.057 \\
\hline CA/TA 2013 & 0.7 & 0.84 & 0.67 & 0.76 & 2920.5 & 0.164 \\
\hline CA/TA 2014 & 0.67 & 0.82 & 0.67 & 0.78 & 3126.5 & 0.472 \\
\hline CA/TA 2015 & 0.58 & 0.68 & 0.68 & 0.77 & 3126 & 0.471 \\
\hline Receivables/TA2012 & 0.27 & 0.18 & 0.21 & 0.15 & 2885 & 0.232 \\
\hline Receivables/TA2013 & 0.28 & 0.2 & 0.21 & 0.16 & 2712 & 0.055 \\
\hline Receivables/TA2014 & 0.27 & 0.17 & 0.2 & 0.15 & 2877 & 0.168 \\
\hline Receivables/TA2015 & 0.26 & 0.14 & 0.2 & 0.14 & 3111 & 0.657 \\
\hline Inventories/TA 2012 & 0.24 & 0.12 & 0.27 & 0.24 & 2870 & 0.119 \\
\hline Inventories/TA 2013 & 0.25 & 0.15 & 0.29 & 0.25 & 2875 & 0.123 \\
\hline Inventories/TA 2014 & 0.23 & 0.12 & 0.30 & 0.27 & 2622 & 0.018 \\
\hline Inventories/TA 2015 & 0.12 & 0.12 & 0.39 & 0.33 & 1479 & 0.000 \\
\hline
\end{tabular}

Source: Author's work. 
Based on the conducted analysis, several inferences may be drawn from the abovepresented findings. Findings indicate that lower prediction accuracy of the Z-score model comes as a result of fraudulent reporting, which is in line with Liou and Yang (2008). However, several studies from the CEE region recommended reestimating the variable coefficients of the Zscore model to adjust the model to the specific business environment and to improve prediction accuracy (Boda \& Uradnicek, 2016, Csikosova et al., 2019), or to combine the model with the neural network model (Kubickova \& Nulicek, 2019). Furthermore, the research depicts that abnormal increases in Z-score in years closer to the bankruptcy year were associated with the manipulative behavior of failing companies and misleading financial statement information. Therefore, it is strongly recommended to use a combination of two or more models for bankruptcy prediction and financial statement manipulation for several consecutive years, accompanied by the ratio estimates of liquidity, solvency, and profitability, which is aligned with Grove et al. (2010). The significant difference between failing and non-failing companies is evident in three out of five Z-score variables: WC/TA, EBIT/TA, and the BV of equity/TL. Following M-score findings, the failing companies, compared to the non-failing companies, are demonstrating engagement in cost deferral, a significant increase in positive accruals, a constant increase in indebtedness, significant drop in sales, and deterioration of gross margins. The red flags become evident two to three years before filing for bankruptcy. In addition to red flags that could be identified through the Z-score and M-score models, there are several other ratios that are indicators of financial distress. A decline in the following variables: WCP, CR, RTR; increase in DR; and very low ROA and ROE are among the first signs of the company's deteriorating health. As the company's health deteriorates, companies are increasingly turning toward loans, where they see the possibility of rescuing from increasingly certain bankruptcy. At the same time, higher positive accruals and cost deferrals indicate that the company's management is revising its estimates, which results in income smoothing.

With respect to the research limitations, the time period covered is rather short, where financial statement data for a longer period would provide a better trend analysis of failing SMEs in comparison with non-failing ones. Furthermore, the sample size in terms of the industry and number of companies observed represent one of the study limitations, where a greater number of companies or comparison of different industries would provide better insight into the investigated topic.

\section{CONCLUSION}

This research indicates that it is possible to detect the possibility of bankruptcy two to three years prior to filing for bankruptcy through financial distress indicators and is using two or more models together as a classification tool. At the same time, aligned with financial distress, red flags that point to the increased likelihood of earnings manipulation become evident through deteriorating gross margins, higher leverage, higher positive accruals, and engagement in cost deferral. The research findings also indicate that ratio analysis can be used as a tool to distinguish between financially distressed and nondistressed companies, revealing the concern areas that should be the subject of further investigation. Hence, working capital productivity, current ratio, debt ratio, receivables turnover, return on assets, return on equity, and inventories to total assets have significant power to detect companies that are within easy reach of bankruptcy, especially when these are observed over a period of time. Furthermore, the main findings for financially distressed SMEs in the wholesale and retail industry show that these companies are highly leveraged and prone to engage in earnings management through positive accruals and cost deferrals.

Concerning the transition economy challenges, SMEs in Bosnia and Herzegovina are not motivated with bonus payments that would boost the manager's performance and urge them to increase profits using various means, but rather vice versa. Often, companies are inclined to report less profit to pay lower taxes. However, the state of financial distress urges companies to use various means to prevent impending bankruptcy. It may refer to the commonly used creative accounting practices that are "within legal limits," or it may include more alarming actions that, as a consequence, have misleading 
financial statements. This research shows how models for bankruptcy prediction and models for financial statement manipulation work together and, as such are highly convergent in depicting a company's financial health.

Bearing in mind the above stated, and given the availability of tools and techniques, proper and timely reaction of responsible authorities may prevent or at least mitigate consequences of fraudulent reporting.

However, there is always a space for future research in order to build a more comprehensive approach in assessing the pre-bankrupt financial condition of SMEs. Based on the above-stated findings, one of the aspects that require further investigation refers to the conditions under which financially distressed companies are being allowed to take on more loans. Also, a specific focus should be on measuring discretionary and non-discretionary accruals, which would provide a more reliable picture of earnings management practices. Furthermore, analysis of auditor reports for financially distressed SMEs would be an excellent way to compare the results of ratio analysis with the expert opinion.

\section{REFERENCES}

Abu Bakar, D. B., \& bin Yahya, M. H. (2021). Impact of Financial Information Fraudulence to Financial Distress in Malaysia. Turkish Journal of Computer and Mathematics Education (TURCOMAT), 12(6), 896-914. https://doi.org/10.17762/turcomat.v12i6.23 67

Altman, E. I. (1968). Financial Distress, Discriminant Analysis and the Prediction of Corporate Bankruptcy. The Journal of Finance, 23(4), 589-609.

Altman, E., I. (1983). Corporate Financial Distress: A Complete Guide to Predicting, Avoiding, and Dealing with Bankruptcy (Frontiers in Finance Series) (1st ed.). Wiley.

Association of Certified Fraud Examiners. (2020). Report to the Nations 2020 Global Study on Occupational Fraud and Abuse. https://acfepublic.s3-us-west2.amazonaws.com/2020-Report-to-theNations.pdf

Beneish, M. D. (1999). The Detection of Earnings Manipulation. Financial Analysts Journal,
55(5), 24-36.

https://doi.org/10.2469/faj.v55.n5.2296

Bisogno, M., \& De Luca, R. (2015). Financial Distress and Earnings Manipulation: Evidence from Italian SMEs. Journal of Accounting and Finance, 4(1), 42-51.

Bisogno, M., Restaino, M., \& Di Carlo, A. (2018). Forecasting and preventing bankruptcy: A conceptual review. African Journal of Business Management, 12(9), 231-242. https://doi.org/10.5897/ajbm2018.8503

Boda, M., \& Úradníček, V. (2016). The Portability of Altman's Z-score Model to Predicting Corporate Financial Distress of Slovak Companies. Technological and Economic Development of Economy, 22(4), 532-553. https://doi.org/10.3846/20294913.2016.119 7165

Campa, D., \& Camacho-Miñano, M. D. M. (2014). Earnings management among bankrupt non-listed firms: evidence from Spain. Spanish Journal of Finance and Accounting / Revista Española de Financiación y Contabilidad, 43(1), 3-20. https://doi.org/10.1080/02102412.2014.890 820

Chen, Y., Chen, C., \& Huang, S. (2010). An Appraisal of Financially Distressed Companies' Earnings Management. Pacific Accounting Review, 22(1), 22-41. https://doi.org/10.1108/0114058101103420 9

Csikosova, A., Janoskova, M., \& Culkova, K. (2019). Limitation of Financial Health Prediction in Companies from PostCommunist Countries. Journal of Risk and Financial Management, 12(1), 15. https://doi.org/10.3390/jrfm12010015

Dalnial, H., Kamaluddin, A., Sanusi, Z. M., \& Khairuddin, K. S. (2014). Accountability in Financial Reporting: Detecting Fraudulent Firms. Procedia - Social and Behavioral Sciences, 145, 61-69. https://doi.org/10.1016/j.sbspro.2014.06.011

Dani, R. M., Ismail, W. A. W., \& Kamarudin, K. A. (2013). Can Financial Ratios Explain the Occurrence of Fraudulent Financial Statements? The 5th International Conference on Financial Criminology (ICFC), N/A(N/A), 345-354. 
Dechow, P. M., Ge, W., Larson, C. R., \& Sloan, R. G. (2011). Predicting Material Accounting Misstatements. Contemporary Accounting Research, 28(1), 17-82. https://doi.org/10.1111/j.19113846.2010.01041.X

Dechow, P. M., Sloan, R. G., \& Sweeney, A. P. (1995). Detecting Earnings Management. American Accounting Association, 70(2), 193-225. https://www.jstor.org/stable/248303?seq=1

Dichev, I. D., \& Dechow, P. M. (2002). The Quality of Accruals and Earnings: The Role of Accrual Estimation Errors. The Accounting Review, 77, 35-59. https://doi.org/10.2139/ssrn.277231

Djuric, D., \& Jovanovic, V. (2019). “Too big to fail"? The Agrokor case and its impact on West Balkan economies. International Insolvency Review, 28(1), 22-43. https://doi.org/10.1002/iir.1327

European Commission. (2019, May). Analytical Report - Commission Opinion on Bosnia and Herzegovina's application for membership of the European Union (COM(2019) 261 final).

Gerantonis, N., Vergos, K., \& Christopoulos, A. G. (2009). Can Altman Z-score Models Predict Business Failures in Greece. Research Journal of International Studies, 12(N/A), 21-28.

Grove, H., Cook, T., Streeper, E., \& Throckmorton, G. (2010). Bankruptcy and Fraud Analysis: Shorting and Selling Stocks. Journal of Forensic \& Investigative Accounting, 2(2), 276-293.

Harrington, C. (2005). Detecting Financial Statement Fraud. New Perspectives Association of Healthcare Internal Auditors, 26-27.

Jones, J. J. (1991). Earnings Management During Import Relief Investigations. Journal of Accounting Research, 29(2), 193. https://doi.org/10.2307/2491047

Kiaupaite-Grushniene, V. (2016, December). Altman Z-score Model for Bankruptcy Forecasting of the Listed Lithuanian Agricultural Companies. In J. Alver (Ed.), 5th International Conference on Accounting, Auditing, and Taxation: Advances in
Economics, Business and Management Research (pp. 222-234). Atlantis Press. https://doi.org/10.2991/icaat-16.2016.23

Kothari, S., Leone, A. J., \& Wasley, C. E. (2005). Performance matched discretionary accrual measures. Journal of Accounting and Economics, 39(1), 163-197. https://doi.org/10.1016/j.jacceco.2004.11.002

Kubíčková, D., \& Nulíček, V. (2019). The Prediction Ability of New Bankruptcy Models in National Environment. Proceedings of the International Scientific Conference Hradec Economic Days 2019 Part I. Published. https://doi.org/10.36689/uhk/hed/2019-01050

Lesáková, U., Gundová, P., \& Vinczeová, M. (2020). The practice of use of models predicting financial distress in Slovak companies. Journal of Eastern European and Central Asian Research (JEECAR), 7(1), 122136. https://doi.org/10.15549/jeecar.v7i1.369

Liou, F., \& Yang, C. (2008). Predicting Business Failure Under the Existence of Fraudulent Financial Reporting. International Journal of Accounting \& Information Management, 16(1), 74-86. https://doi.org/10.1108/18347640810887771

MacCarthy, J. (2017). Using Altman Z-score and Beneish M-score Models to Detect Financial Fraud and Corporate Failure: A Case Study of Enron Corporation. International Journal of Finance and Accounting, 6(6), 159-166. https://doi.org/10.5923/j.ijfa.20170606.01

Mahama, M. (2015). Detecting Corporate Fraud and Financial Distress Using the Altman and Beneish Models. International Journal of Economics, Commerce and Management, $3(1), 1-18$.

Ofori, E. (2016). Detecting Corporate Financial Fraud Using Modified Altman Z-Score and Beneish M-Score. The Case of Enron Corp. Research Journal of Finance and Accounting, 7(4), 59-65.

Ogachi, D., Ndege, R., Gaturu, P., \& Zoltan, Z. (2020). Corporate Bankruptcy Prediction Model, a Special Focus on Listed Companies in Kenya. Journal of Risk and Financial 
Management, 13(3), 47-61. https://doi.org/10.3390/jrfm13030047

Perols, J. L., \& Lougee, B. A. (2011). The Relation Between Earnings Management and Financial Statement Fraud. Advances in Accounting, 27(1), 39-53. https://doi.org/10.1016/j.adiac.2010.10.004

Sloan, R. G. (1996). Do Stock Prices Fully Reflect Information in Accruals and Cash Flows about Future Earnings? The Accounting Review, 71(3), 289-315.

Svabova, L., Kramarova, K., Chutka, J., \& Strakova, L. (2020). Detecting Earnings Manipulation and Fraudulent Financial Reporting in Slovakia. Oeconomia Copernicana, 11(3), 485-508. https://doi.org/10.24136/oc.2020.020

Tarjo, \& Herawati, N. (2015). Application of Beneish M-Score Models and Data Mining to Detect Financial Fraud. Procedia - Social and Behavioral Sciences, 211, 924-930. https://doi.org/10.1016/j.sbspro.2015.11.122

Warshavsky, M. (2012). Analyzing Earnings Quality as a Financial Forensic Tool. Financial Valuation and Litigation Expert Journal, N/A(39), 16-20.

\section{ABOUT THE AUTHORS}

Elvisa Buljubasic Musanovic, email: elvisa.buljubasic@ibu.edu.ba

Elvisa Buljubasic Musanovic is a senior teaching assistant at International Burch University and has over 5 years of experience in academia. Besides academic experience, she has been involved in the 5-year USAID Fiscal Sector Reform Activity project whose aim was to strengthen the public finance sector in Bosnia and Herzegovina. Her areas of interest include accounting, forensic accounting, and public finance. Currently, she is pursuing a doctorate degree in forensic accounting. She is the author of several international publications in the areas of accounting and finance.

Dr. Sanel Halilbegovic is a banking and finance professor at International Burch University for the past 5 years. He earned his Ph.D. in International Finance from the American University in $\mathrm{BiH}$, an MBA degree from the Northeastern Illinois University in Chicago, USA. He comes with 25 years of experience in corporate finance and investment finance, and since he is an avid stocks/options/crypto trader, his area of expertise and research, besides general finance, is in investment portfolio finance, forensic accounting/ finance, and trading strategies and models. 